\title{
Effect of calcium and magnesium silicate on the growth of the castor oil plant subjected to salinity levels
}

\section{Efeito de silicato de cálcio e magnésio sobre o crescimento de plantas de mamoneira submetidas a níveis de salinidade}

\author{
José Félix de Brito Neto ${ }^{1 *}$; Napoleão de Esberard Macêdo Beltrão ${ }^{2}$; \\ João Paulo Gonsiorkiewicz Rigon ${ }^{3}$; Silvia Capuani ${ }^{3}$
}

\begin{abstract}
Salt stress decreases the osmotic potential of soil solution causing water stress, causing toxic effects in the plants resulting in injuries on the metabolism and nutritional disorders, thus compromising the plant growth, resulting in lower production. The calcium silicate and magnesium can perform the same function as limestone, besides providing silicon to plants, may also contribute to the resistance of plants to salt stress. Thus, the objective of this study was to evaluate the effect of calcium and magnesium silicate on the growth of the castor oil plant BRS Energia cultivated under saline conditions. This study evaluated plant height, stem diameter, number of leaves, leaf area, dry weight of shoot and root, and soil chemical characteristics. There was no interaction between factors of salinity level and of silicate level regarding the evaluated variables. There was a direct relationship between salinity levels and plant growth in height and stem diameter. The $\mathrm{K}$ concentration in soil were affected by salinity levels.
\end{abstract}

Key words: Salt stress, silicate application, growth, plants

\section{Resumo}

O estresse salino diminui o potencial osmótico da solução do solo causando estresse hídrico, provocando efeitos tóxicos nas plantas que resultam em injúrias no metabolismo e desordens nutricionais, comprometendo assim o crescimento das plantas, resultando em menor produção. $\mathrm{O}$ silicato de cálcio e magnésio pode desempenhar a mesma função do calcário, além de fornecer silício para as plantas, podendo ainda, contribuir para a resistência de plantas ao estresse salino. Nesse sentido, objetivou-se com esse trabalho avaliar o efeito do silicato de cálcio e magnésio no crescimento da mamoneira BRS Energia cultivada sob condições salinas. Avaliou-se a altura da planta, diâmetro do caule, número de folhas, área foliar, massa seca da parte aérea e da raiz e as características químicas do solo. Não houve interação entre os fatores níveis de salinidade e silicato sobre as variáveis analisadas. Houve relação direta entre os níveis de salinidade e o crescimento da planta em altura e diâmetro do caule. Os teores de $\mathrm{K}$ no solo foram influenciados pelos níveis de salinidade.

Palavras-chave: Estresse salino, silicatagem, crescimento, plantas

\footnotetext{
${ }^{1}$ Doutorando em Agronomia e Agricultura, Faculdade de Ciências Agronômicas, Universidade Estadual Paulista "Júlio de Mesquita Filho", FCA/UNESP, Botucatu, SP. E-mail: felix@cnpa.embrapa.br

${ }^{2}$ Pesquisador da Empresa Brasileira de Pesquisa Agropecuária, Centro Nacional de Pesquisa de Algodão, Centenário, Campina Grande, PB. E-mail: napoleão.beltrão@embrapa.br

${ }^{3}$ Mestrando(a) em Agronomia/Agricultura, FCA/UNESP, Botucatu. SP. E-mail: jprigon@fca.unesp.br; silviacapuani@fca.unesp.br

* Author for correspondence
} 


\section{Introduction}

The castor oil plant (Ricinus communis L.) of the family Euphorbiaceae is characterized by its ruggedness chiefly because of its easy adaptability to different ecosystems (OLIVEIRA, 2011). In countries where there are arid and semiarid regions, the effect of salinity on the growth and the development of plants have been discussed by researchers because of the socioeconomic problems that have been caused by it. The research has contributed to reducing its effects on the plants through the evaluation of methods for soil remediation and through genetic breeding (BROETTO, 1995). In Brazil, the castor oil plant is grown in the Southeast, South and Northeast (NAZARENO et al., 2011); the Northeast region accounts for $85 \%$ of the area planted with this crop, increasing national production by $78 \%$ more berries.

It is noteworthy that despite its hardiness, its yield may be reduced because of the influence of biotic and abiotic factors, such as the availability of nutrients (COSTA et al., 2011) and the accumulation of salts in soil and water. Fagan et al. (2009) reported that in the semi-arid region, there is poor spatial and temporal distribution of rainfall, and high water consumption, mainly for irrigated agriculture and, as a result of inadequate management, can raise the level of salts in the soil. The high salt content in the soil and irrigation water in semi-arid regions is a limiting factor for the cultivation of the castor oil plant, mainly through salt stress causing reductions in germination, growth and production, which result in morphological, structural and metabolic changes. This effect is due to the increase in water potential of the medium hinders the absorption of water, thereby damaging the processes of division and cell elongation and the mobilization of the reserves necessary for the metabolic processes of plants (SILVA et al., 2011).

The use of silicon can be an alternative to minimize the negative effect of salts on the cultures (LIMA et al., 2011) because silicon, although not considered an essential element (GIONGO; BOHNEN, 2011), can optimize some desirable physiological processes to increase significantly the yield of some species through the accumulation and polymerization of silicate in the epidermal cells. This forms a double-layer silicon cuticle that reduces perspiration substantially, resulting in lower water consumption (PEIXOTO et al., 2011) and, therefore, increased tolerance to the osmotic effect caused by salinity. The purpose of this work was to evaluate the effect of $\mathrm{Ca}$ and $\mathrm{Mg}$ silicate on the growth of the castor oil plant and as an attenuator of soil salinity.

\section{Materials and Methods}

The experiment was conducted under glass greenhouse conditions with a partial environmental control in the city of Campina Grande, Paraíba, Brazil, and the greenhouses belong to Embrapa Cotton, a unit of Embrapa (Brazilian Agricultural Research Corporation). The experiment was conducted from July to October 2010, and the cultivar BRS Energia was used. In each experimental unit, there was a plastic vessel with a capacity of 20 L, which was filled with a soil material classified as Regosols, which passed through a 4-mm sieve (EMBRAPA, 2006). The soil fertility characteristics were evaluated according to the methodology that was proposed by Embrapa (1997) (Table 1).

A completely randomized design was used in the experiment and included a factorial scheme of $5 \times 2$ with five salinity levels $\left(0.0 \mathrm{dSm}^{-1} ; 2.0 \mathrm{dSm}^{-}\right.$ ${ }^{1} ; 4.0 \mathrm{dSm}^{-1} ; 6.0 \mathrm{dSm}^{-1}$; and $8.0 \mathrm{dSm}^{-1}$ ) applied through irrigation water daily at the amount of $200 \mathrm{~mL}$ per pot, which was added according to the evapotranspiration of the plant (COSTA et al., 2011). The silicate of calcium and magnesium (16.6 $\mathrm{g} \mathrm{pot}^{-1}$ ), corresponding to $2000 \mathrm{~kg} \mathrm{ha}^{-1}$ and without application of silicate, with five replicates, totaled 50 experimental units. Agro-silicon was used $\left(42 \% \mathrm{CaO} ; 12 \% \mathrm{MgO}\right.$; and $\left.23 \% \mathrm{SiO}_{2}\right)$ as a source of silicon. The soils were subjected to NPK 
fertilization, which was based on soil analysis. Doses of phosphorus and potassium were placed in foundation, together with the dose of $\mathrm{Ca}$ and $\mathrm{Mg}$ silicate. The application of the doses of PK and silicate in the soil of each vessel was followed by an incubation period for three weeks, and water was added in an amount that corresponded to $50 \%$ of the field capacity. The saline solution that comprised sodium chloride and calcium and magnesium chloride was applied by watering at the interval of two days in an amount that corresponded to $70 \%$ of the field capacity.

Table 1. Initial chemical characteristics of soil fertility for the soil used in the experiment.

\begin{tabular}{|c|c|c|c|c|c|c|c|c|c|c|c|}
\hline pH & $\mathbf{P}$ & $\mathbf{K}^{+}$ & $\mathbf{N a}^{+}$ & $\mathbf{H}+\mathrm{Al}^{3+}$ & $\mathbf{A l}^{3+}$ & $\mathbf{C a}^{2+}$ & $\mathbf{M g}^{2+}$ & SB & CEC & $\mathbf{V}$ & M.O \\
\hline $\mathrm{H}_{2} \mathrm{O}$ & $--m \xi$ & $\mathrm{dm}^{-3}--$ & ---- & 2. & - & $\mathrm{mol}_{\mathrm{c}}$ & & & & $0^{-}$ & \\
\hline 5.8 & 7.5 & 86.02 & 0.05 & 1.57 & 0.00 & 1.09 & 2.48 & 92.5 & 5.41 & 71 & 0.76 \\
\hline
\end{tabular}

Source: Elaboration of the authors.

After the incubation period, three seeds were sown in each vessel, and then, each vessel was thinned, leaving one plant per vessel. Nitrogen was applied to the plots; half of the dose was applied 15 days after sowing, and the other half of the dose was applied 30 days after sowing. The growth evaluation was performed at intervals of 15 days. The height data were taken using a millimeter ruler; stem diameter data were taken using a digital caliper; and data on the number of leaves and the leaf area were taken based on the methodology proposed by (SEVERINO et al., 2006). A hundred days after sowing, the aerial part of the plants of each vessel was cut at $1 \mathrm{~cm}$ from the soil. Afterward, the plant materials (aerial part and root) were washed under running tap water.

Next, the material was packed in a perforated paper bag and taken to a greenhouse with forced air at $70^{\circ} \mathrm{C}$ until constant weight and was then weighed to obtain the dry matter. After the dry matter of the aerial part was weighed, it was triturated in a Wiley mill. Then, determinations of macronutrients and micronutrients in the dry matter of the leaf were performed, and the methodology proposed by Embrapa (1997) was adopted. All of the data were submitted to analysis of variance using the statistics program SAS, and the averages were compared using Tukey's test at 5\% probability. The polynomial regression equations were adjusted to determine the effects of the calcium and magnesium silicate on the analyzed variables.

\section{Results and Discussion}

By analyzing the results of the analysis of variance, it can be stated that there was no interaction between the factors of levels of salinity and silicate on the analyzed variables, which demonstrates that they are mutually independent. However, the salinity levels significantly influenced the variables of plant height, stem diameter and leaf area. Nevertheless, there was no significant effect of the silicate on the analyzed variables in the plant (Table 2). These results differed from those found by Prado and Natale (2004), who noted an increase in the stem diameter of passion fruit and corn plants when they were fertilized with silicon. It was also found that the silicate was inefficient in controlling the depressive effects of salinity on plant dry mass production, as stated by Bradbury and Ahmad (1990) and Liang et al. (1996) when working with other cultures. Research conducted with tomatoes that showed the beneficial effects of silicon on plant growth in saline conditions corroborates the results found by (DATNOFF; SNYDER; KORNDÖFER, 2001) with other species under biotic and abiotic stresses. 
Table 2. Summary of the analyses of variance for the variables plant height, stem diameter, number of leaves, leaf area, root dry mass and leaf dry mass.

\begin{tabular}{|c|c|c|c|c|c|c|c|}
\hline \multirow[b]{2}{*}{ SV } & & \multicolumn{6}{|c|}{ Mean square } \\
\hline & & Plant height & $\begin{array}{c}\text { Stem } \\
\text { diameter }\end{array}$ & $\begin{array}{c}\text { Number of } \\
\text { leaves }\end{array}$ & Leaf area & $\begin{array}{l}\text { Root dry } \\
\text { mass }\end{array}$ & $\begin{array}{c}\text { Leaf dry } \\
\text { mass }\end{array}$ \\
\hline No. of salts & 4 & $811.94^{* *}$ & $9.01^{* *}$ & $0.62^{\text {ns }}$ & $5,646.84^{*}$ & $1.45^{\mathrm{ns}}$ & $14.80^{\text {ns }}$ \\
\hline Silicate & 1 & $208.89^{\mathrm{ns}}$ & $1.58^{\mathrm{ns}}$ & $3.92^{\mathrm{ns}}$ & $5,570.23^{\mathrm{ns}}$ & $5.79^{\mathrm{ns}}$ & $76.97^{\mathrm{ns}}$ \\
\hline Sal. x Sil. & 4 & $29.20^{\mathrm{ns}}$ & $1.31^{\mathrm{ns}}$ & $1.12^{\mathrm{ns}}$ & $4,814.35^{\mathrm{ns}}$ & $6.78^{\mathrm{ns}}$ & $19.19^{\mathrm{ns}}$ \\
\hline C.V. $(\%)$ & & 13.33 & 10.15 & 31.63 & 48.03 & 30.70 & 19.19 \\
\hline
\end{tabular}

* Significant at $5 \%$ probability by Tukey's test. ** Significant at $1 \%$ probability by Tukey's test. ${ }^{\text {ns }}$ Not significant by Tukey’s test. Source: Elaboration of the authors.

According to the average values for the analyzed variables, the salinity levels significantly influenced the plant height, the stem diameter and the leaf area. There was no significant difference for the variables number of leaves, dry mass of root and shoot dry mass from the levels of salinity. However, there was no significant difference between the silicate doses for the analyzed variables (Table 2). Cavalcanti et al. (2005) found a reduction of $23.40 \%$ (5.85\% for every $\mathrm{dSm}^{-1}$ ) in plant height for the cultivar BRS Nordestina in a study about the behavior of the irrigated castor oil plant, in which electrical conductivity of water ranged from $0.7 \mathrm{dSm}^{-1}$ to 4.7 $\mathrm{dSm}^{-1}$. When Silva (2004) studied BRS Paraguaçu with $\mathrm{ECw} 0.7 \mathrm{dSm}^{-1}$ ranging from 1 to $8.7 \mathrm{dS} \mathrm{m}^{-1}$, he observed a decrease in plant height of $78.10 \%$ $\left(9.76 \%\right.$ for each $\left.\mathrm{dSm}^{-1}\right)$.

Table 3. Average values of plant height, stem diameter, number of leaves, leaf area, root dry mass and leaf dry mass.

\begin{tabular}{|c|c|c|c|c|c|c|}
\hline \multirow[b]{2}{*}{$\begin{array}{l}\text { Salinity } \\
\text { levels }\end{array}$} & \multicolumn{6}{|c|}{ Variables } \\
\hline & $\begin{array}{l}\text { Plant height } \\
\text { (cm) }\end{array}$ & $\begin{array}{l}\text { Stem diameter } \\
(\mathrm{mm})\end{array}$ & $\begin{array}{l}\text { Number } \\
\text { of leaves }\end{array}$ & $\begin{array}{c}\text { Leaf area } \\
\left(\mathrm{cm}^{2}\right)\end{array}$ & $\begin{array}{l}\text { Root dry } \\
\text { mass (g) }\end{array}$ & $\begin{array}{l}\text { Leaf dry } \\
\text { mass (g) }\end{array}$ \\
\hline 0 & 68.68 & 12.95 & 5.10 & $6,680.46$ & 5.94 & 15.42 \\
\hline 2 & 66.10 & 12.90 & 4.70 & $6,563.21$ & 5.51 & 15.88 \\
\hline 4 & 58.10 & 12.81 & 4.80 & $6,193.64$ & 5.74 & 15.84 \\
\hline 6 & 55.70 & 12.55 & 4.50 & $5,206.71$ & 6.26 & 14.88 \\
\hline 8 & 46.00 & 10.71 & 4.50 & $4,981.84$ & 5.37 & 12.94 \\
\hline \multicolumn{7}{|c|}{ Silicate doses } \\
\hline 0 & 56.87 & 12.20 & 4.44 & $6,650.22$ & 6.10 & 16.23 \\
\hline 16.6 & 60.96 & 12.56 & 5.00 & $6,545.34$ & 5.42 & 13.75 \\
\hline
\end{tabular}

Source: Elaboration of the authors.

There was a direct relationship between the salinity levels and the height growth of the plant. A decreasing quadratic effect on the plant height was found because of the increase in the salt concentration, and the highest concentration (8 $\mathrm{dSm}^{-1}$ ) was responsible for the highest reduction in plant height (Figure 1A). This inhibition in growth was primarily caused by the toxic effects of the salts that were absorbed by the plants, namely, $\mathrm{Na}^{+}$and $\mathrm{Cl}^{-}$. Alternatively, this inhibition may have been caused by a decrease in osmotic adjustment capacity of the culture. Additionally, the full potential of water, which may have been caused by increased salt concentration, may have hindered the process 
of expansion and cell division. This result agrees with papers that are found in the scientific literature, where the increased salinity of the water and soil salinity affect the growth of most crop plants, especially those that are sensitive or moderately sensitive to salinity, such as the castor oil plant (AYERS; WESTCOT, 1999). In saline soils, water deficiency is the leading cause of reduced productivity of the plant, altering the growth and photosynthesis (PIMENTEL et al., 2002). There is also that the reduction of leaf growth in plants, reduced production of dry matter of shoot and root can be directly influenced by the accumulation of high levels of $\mathrm{Na}^{+}$and $\mathrm{Cl}^{-}$in the leaves, causing a decrease in the relative content of water pressure and water potential, cell turgor (LARCHER, 2000).

In general, the plants that were subjected to salinity levels had the same behavior regarding the height of the plants throughout the crop cycle; that is, they had a higher growth up to $100 \mathrm{DAS}$, as observed in the slopes of the curves. However, there was variation in the values for plant height due to the treatments that were applied during the experiment, mainly for the highest salinity level (8 $\mathrm{dSm}^{-1}$ ), which caused the highest reduction in plant height growth (Figure 1B).

Figure 1. Plant height $(\mathrm{cm})(A)$ and height growth curve $(\mathrm{cm})(B)$ according to the salinity levels $\left(\mathrm{dSm}^{-1}\right)$ and to different seasons (days).

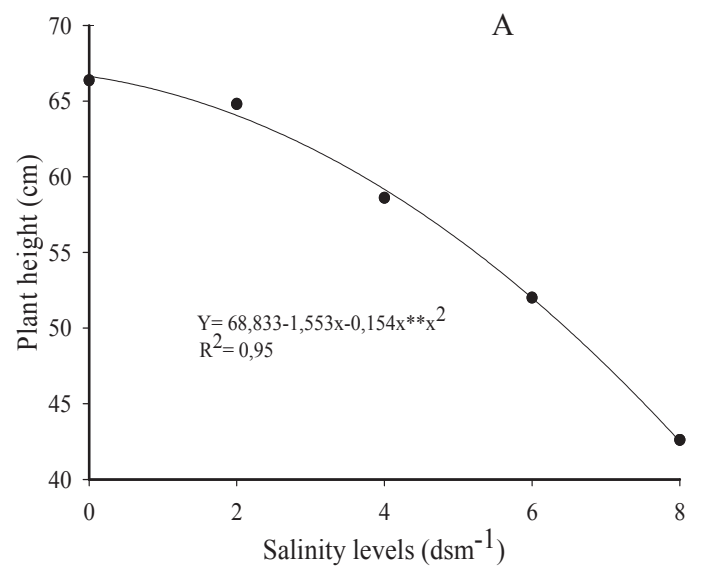

Source: Elaboration of the authors.

In plants with a low tolerance to salinity, the formation of seedlings, growth, productivity and product quality can be strongly affected (COSTA et al., 2011), probably because of reductions in the water absorption and metabolic activity of the plants. These reductions have been largely related to nutritional deficiencies (SZABOLCS 1994; SHANNON, GRIEVE, FRANCOIS, 1994). According to Hsiao and $\mathrm{Xu}$ (2000), salinity affects leaf growth more than root growth, which shows that it may be caused

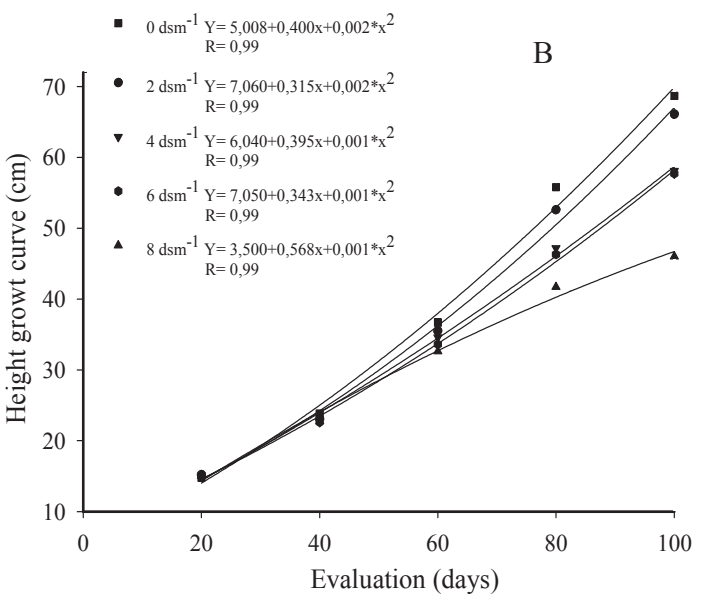

by factors that are associated to water stress but not to the specific effects of salts. According to Figure $2 \mathrm{~A}$, the increasing levels of salinity negatively influenced plant growth in diameter stem. The increased levels of salinity promoted the reduction of stem diameter to fit the quadratic model, with the highest level of salts responsible for the smaller diameter stems of the plants when compared with the control. The plants increased their molecular and biochemical mechanisms to tolerate salt stress 
through alternative products and processes. These mechanisms act together (IYENGAR; REDDY, 1996). The strategies used include biochemical accumulation or selective exclusion of ions, control of the entry of ions by roots and transport to the leaves, compartmentalization of ions at the cellular (vacuoles) and structural (leaves) levels, synthesis of osmolytes, changes in photosynthetic pathways, changes in membrane structure, and induction of antioxidant enzymes and hormones.

In addition to cell growth, the tolerance of plants to excess salts involves maintenance of ion transport during growth and the balance between osmotic potential and cell expansion. The increase in salinity causes several chemical deficiencies in the plant (KHAN; UNGAR; WALTER, 2000). The stress caused by the increase of $\mathrm{Na}^{+}$and $\mathrm{Cl}^{-}$in certain plants means that these elements are accumulated in greater amounts in the leaves, followed by the roots.
In this situation, one can observe the antagonistic effect of these ions on the $\mathrm{K}^{+}$, which decreases, particularly in the leaves.

The salinity affects plant development by inhibiting the expansion of the leaf surface and by causing a considerable decrease in the fresh and dry biomass of leaves and roots (TAKEMURA et al., 2000). The increase in the stem diameter of the castor oil plant after it was subjected to the different treatments during the experimental period may be observed in Figure 2B. Similar to that observed for plant height, the highest values for the stem diameter were found at 100 DAS. A similar behavior among the treatments was found in the different seasons. There was not a great difference among the evaluations, except for the treatment with the highest salt concentration $\left(8 \mathrm{dSm}^{-1}\right)$, and this concentration caused the greatest reduction in the stem diameter (Figure 2A).

Figure 2. Stem diameter $(\mathrm{mm})$ and growth curves according to the salinity levels $\left(\mathrm{dsm}^{-1}\right)(\mathrm{A})$ and to different seasons (days) (B).

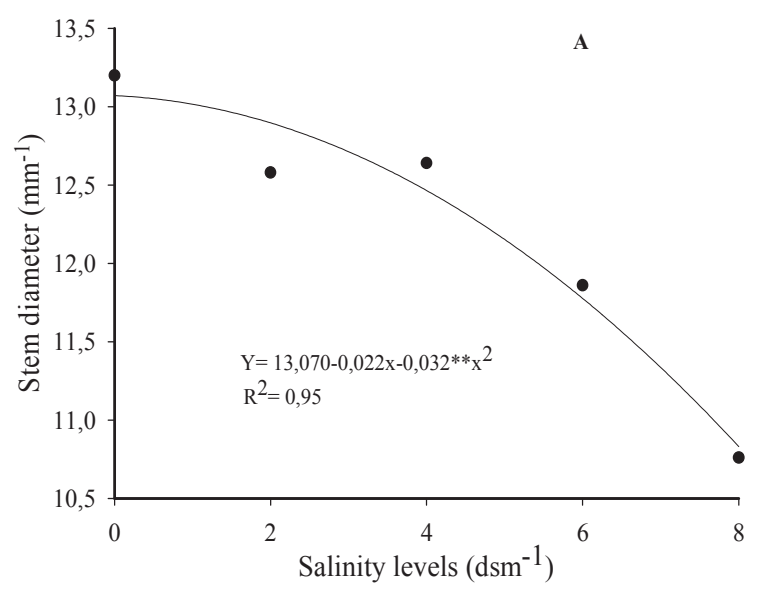

Source: Elaboration of the authors.

There was an effect of the salt levels on the calcium concentration in the soil. In the treatment in which there was no application of calcium and magnesium silicate, the calcium content decreased

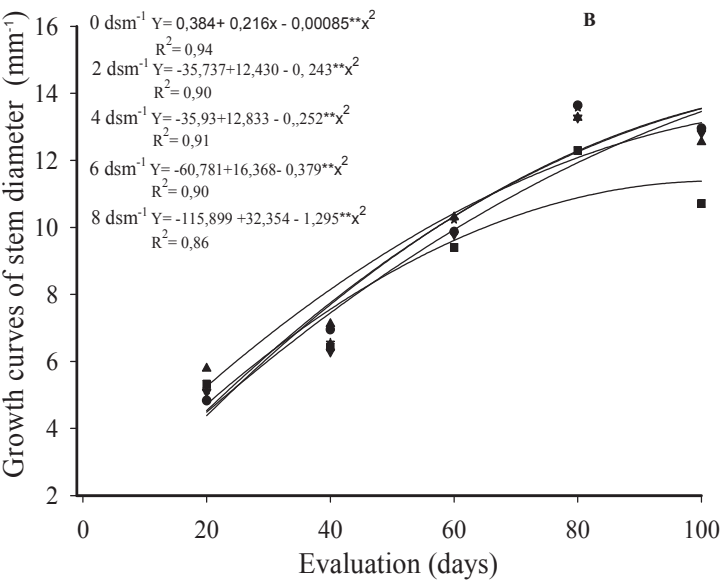

with the increase in the salt concentration to the level of $4 \mathrm{dSm}^{-1}$. When Miranda et al., (2007) worked with salinity levels and silicon doses, they found that the lowest $\mathrm{Ca}^{+2}$ concentration were 
obtained from plants that were treated only with $\mathrm{NaCl}$. However, when the silicon was applied, the $\mathrm{Ca}$ concentration were higher. Nevertheless, the application of calcium silicate and magnesium promoted a greater increase in Ca concentration in the soil when compared with the absence of silicate, and a quadratic fitting with a high determination coefficient $(\mathrm{R}=0.97$ ) can be observed (Figure $3 \mathrm{~A}$ ). This behavior may be explained by the amount of $\mathrm{Ca}$ present in the silicate, which increased the concentration of that element present in the soil. According to Kondörfer, Pereira and Camargo (2002), the silicates, in addition to being a source of calcium and magnesium, are sources of silicon, which is quite beneficial to the growth and development of plants from the physiological and metabolic standpoint.

Similar behavior was observed for the $\mathrm{Mg}$ content in the soil. According to Figure 3B, the $\mathrm{Mg}$ content decreased with increasing salinity with a low point at $4 \mathrm{dSm}^{-1}$ in the absence of silicate and with an increase in $\mathrm{Mg}$ content from this level of salt. However, with the application of calcium silicate and magnesium, it was found that the levels of $\mathrm{Mg}$ increased to values higher than the treatments obtained in the absence of silicate, without any interference from the soil salinity.

Figure 3. Calcium (A) and magnesium (B) concentration in soil according to salinity levels and doses of calcium and magnesium silicate.

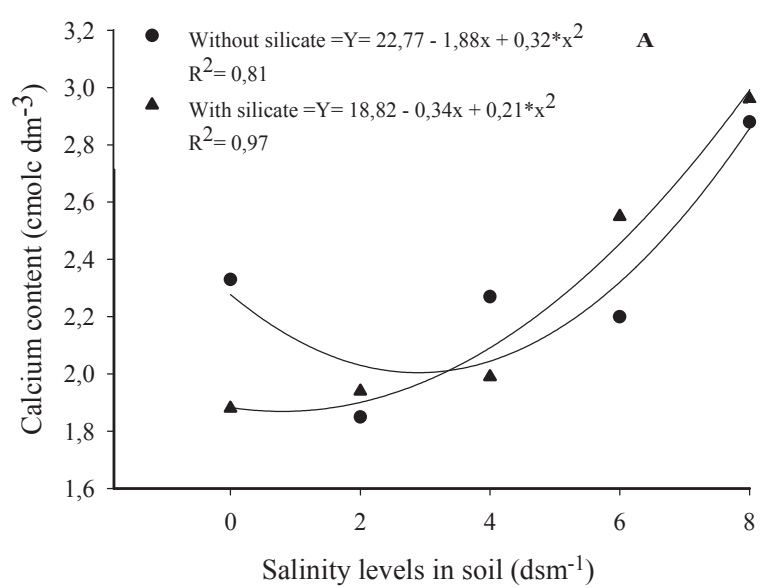

Source: Elaboration of the authors.

The concentration of $\mathrm{K}$ in the soil were influenced by the salinity levels. According to Figure 4A, it is possible that in the absence of silicate, there was a decrease in $\mathrm{K}$ content with a minimum point at the 4 $\mathrm{dSm}^{-1}$ of salts applied to the soil. However, from this level of salts, the K value increased up to $79 \mathrm{mg} \mathrm{dm}^{-}$ ${ }^{3}$. When silicate was added to the treatments, it was observed that the levels of salts used did not affect the $\mathrm{K}$ content in the soil, with quadratic growth of this element with values close to $108 \mathrm{mg} \mathrm{dm}^{-3}$.

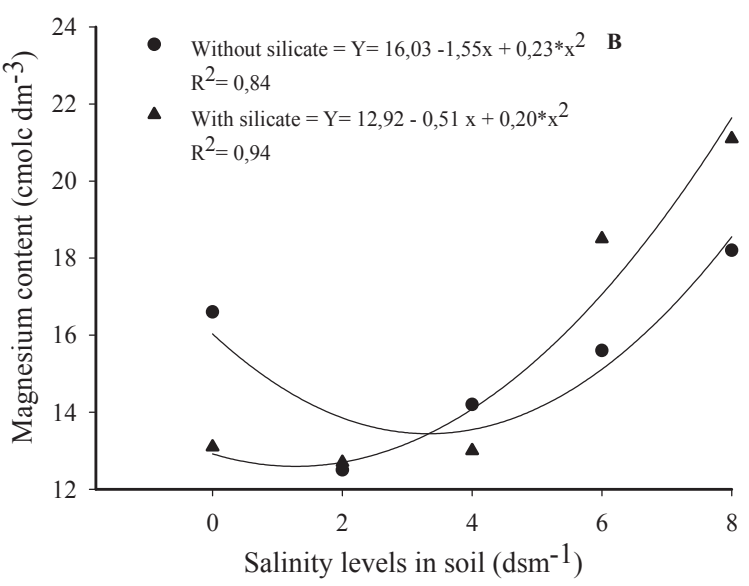

The increase in salt concentration significantly influenced the sodium concentration in soil. From Figure 4B, it is possible to notice that the application of the salt levels linearly increased the $\mathrm{Na}$ concentration in the soil. In saline environments, the salt $\mathrm{NaCl}$ is predominant and causes further damage to plants. The effects on mineral nutrition are mainly because of the toxicity of the ions as a result of the excessive absorption of $\mathrm{Na}^{+}$and $\mathrm{Cl}^{-}$and the nutritional imbalance caused by disturbances in the absorption or distribution of nutrients (YAHYA, 1998). 
Figure 4. Potassium (A) and sodium (B) concentration in soil according to salinity levels and doses of calcium and magnesium silicate.
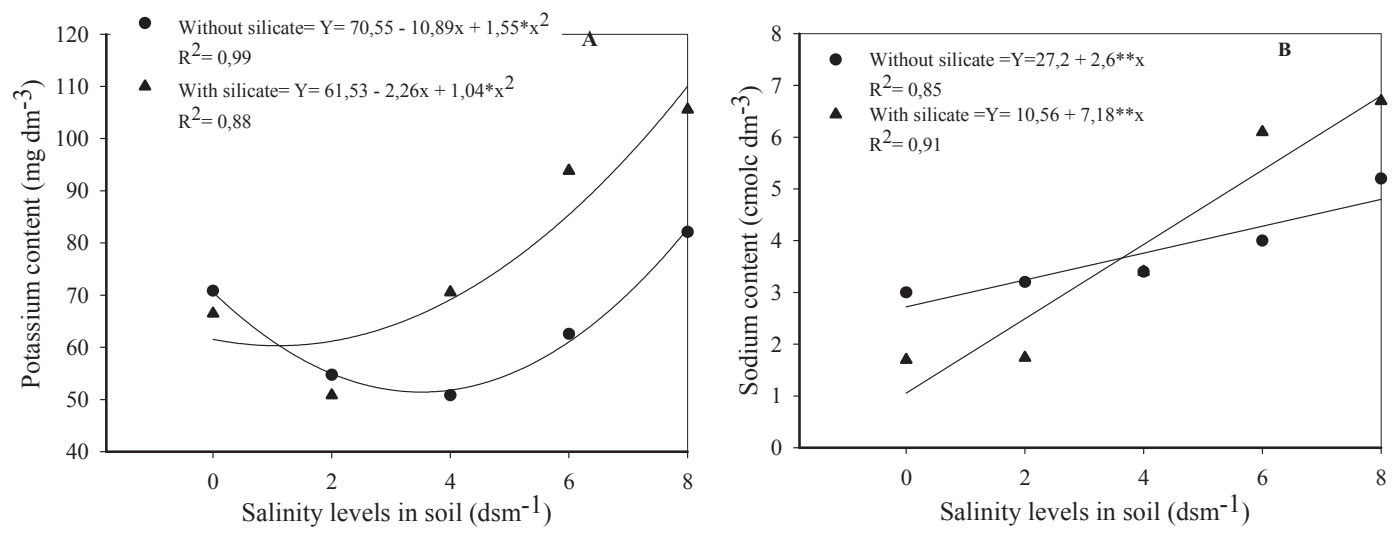

Source: Elaboration of the authors.

According to Larcher (2000), when the $\mathrm{NaCl}$ content in the soil is high, the absorption of nutrients, especially $\mathrm{NO}^{3-}, \mathrm{K}^{+}$and $\mathrm{Ca}^{2+}$, is reduced. It can also be observed that the presence of silicate was inefficient in controlling the increase of sodium in the soil because of the increase in the saline concentration. Most of the species that use the $\mathrm{C}_{4}$ routes of carbon setting require sodium ions. In these plants, the sodium seems to be crucial for the regeneration of the phosphoenolpyruvate, a substrate of the first carboxylation in the $\mathrm{C}_{4}$ routes, for stimulating growth through a greater cell expansion and for partially substituting the potassium as an osmotically active solute (MARSCHNER, 1995).

\section{Conclusions}

The increase in soil salinity from 0 to $8 \mathrm{dSm}^{-1}$ caused a decreasing effect on the plant growth in height and diameter stem.

The $\mathrm{Ca}$ and $\mathrm{Mg}$ concentration in soil increased with the application of silicate, even in the presence of salts $\left(\mathrm{Ca}^{+}, \mathrm{Mg}^{+}, \mathrm{Na}^{+}\right)$.

The $\mathrm{Ca}$ and $\mathrm{Mg}$ silicate, at a dose of $16.6 \mathrm{~g}$ vessel $^{-1}$, was not efficient in mitigating the effects of sodium in the soil.

\section{References}

AYERS, R. S.; WESTCOT, D. W. A qualidade da água na agricultura. Tradução GHEYI, H. R.; MEDEIROS, J. F.; DAMASCENO, F. A. V. Campina Grande: UFPB, 1999. 218 p. (Estudos FAO: Irrigação e Drenagem, 29, revisado 1$)$.

BRADBURY, M.; AHMAD, R. The effect of silicon on the growth of Prosopis juliflora in saline soil. Plant Soil, The Hague, v. 125, n. 1, p. 71-74, 1990.

BROETTO, F. Efeito de estresse salino e biológico sobre o metabolismo de calos e suspensão de células de feijão (Phaseolus vulgaris L.). 1995. Tese (Doutorado em Ciências/Energia Nuclear) - Escola Superior de Agricultura Luiz de Queiroz, Piracicaba.

CAVALCANTI, M. L. F.; FERNANDES, P. D.; GHEVI, H. R.; BARROS JÚNIOR, G.; SOARES, F. A. L.; SIQUEIRA, E. C. Índices ecofisiológicos da mamoneira sob estresse salino. Revista Brasileira de Engenharia Agricola e Ambiental, Campina Grande-PB, v. 9, p. 6670, 2005. Suplemento.

COSTA, F. X.; BELTRÃO, N. E. M.; FILHO, J. S. M.; SILVA, D. P.; DANTAS, G. F.; SILVA, F. E. A. Avaliação da fisiologia e bioquímica da mamoneira em função da aplicação de composto orgânico de lixo e torta de mamona como fertilizantes. Engenharia Ambiental, Espírito Santo do Pinhal, v. 8, n. 1, p. 101-109, 2011.

DATNOFF, L. E.; SNYDER, G. H.; KORNDÖFER, G. H. Silicon in agriculture. Amsterdam: Elsevier, 2001. $403 \mathrm{p}$. 
EMPRESA BRASILEIRA DE PESQUISA AGROPECUÁRIA - EMBRAPA. Centro Nacional de Pesquisa de Solos. Ministério da Agricultura e do Abastecimento. Sistema brasileiro de classificação de solos. 2. ed. Rio de Janeiro: 2006. 306 p.

Centro Nacional de Pesquisa de Solos. Manual de métodos de analise de solo. 2. ed. rev. atual. Rio de Janeiro, 1997. 212 p. (Documentos, 1).

FAGAN, E. B.; PETTER, S. L.; SIMON, J.; BORCIONI, E.; LUZ, J. L.; MANFROM, P. A. Eficiência do uso de água do meloeiro hidropônico. Bioscience Journal, Uberlândia, v. 25, n. 2, p. 37-45, 2009.

GIONGO, V.; BOHNEN, H. Relação entre alumínio e silício em genótipos de milho resistente e sensível a toxidez de alumínio. Bioscience Journal, Uberlândia, v. 27, n. 3, p. 348-356, 2011.

HSIAO, T. C.; XU, L. K. Sensitivity of growth of roots versus leaves to water stress: biophysical analysis and relation to water transport. Journal of Experimental Botany, Oxford, v. 51, n. 350, p. 1595-1616, 2000.

IYENGAR, E. R. R.; REDDY, M. P. Photosynthesis in highly salt tolerant plants. In: PESSERKALI, M. (Ed.). Handbook of photosynthesis. Marshal Dekar: Baten Rose, 1996. p. 897-909.

KHAN, M. A.; UNGAR, I. A.; WALTER, A. M. S. Effects of salinity on growth, water relations and ion accumulation of the subtropical perenial halophyte, Atriplex griffithiivar, stocksii. Annals of Botany, Oxford, v. 85, n. 2, p. 225-232, 2000.

KONDÖRFER, G. H.; PEREIRA, H. S.; CAMARGO, M. S. Silicatos de cálcio e magnésio na agricultura. Uberlândia: GPSi-ICIAG-UFU, 2002. 23 p. (Boletim técnico, 1).

LARCHER, W. Ecofisiologia vegetal. Tradução Carlos Henrique B. A. Prado. São Carlos: Rima, 2000. 531 p.

LIANG, Y.; SHEN, Q.; SHEN, Z.; MA, T. Effects of silicon on salinity tolerance of two barley cultivars. Journal of Plant Nutrition, Philadelphia, v. 19, n. 1, p. 173-183, 1996.

LIMA, M. de A.; CASTRO, V. F.; VIDAL, J. B.; ENÉASFILHO, J. Aplicação de silício em milho e feijão-decorda sob estresse salino. Revista Ciência Agronômica, Fortaleza, v. 42, n. 2, p. 398-403, 2011.

MARSCHNER, H. Mineral nutrition of higher plant. 2. ed. New York: Academy, 1995. 889 p.

MIRANDA, J. R. P.; CARVALHO, J. G. C.; FERNANDES, A. R.; PAIVA, H. N. Produção de biomassa seca e acúmulo de nutrientes e $\mathrm{Na}$ por plantas de moringa (Moringa Oleifera Lam.) cultivadas em solução nutritiva com diferentes níveis de $\mathrm{NaCl}$. Revista de Ciências Agrárias, Belém, n. 47, p. 187-198, jan.jun. 2007.

NAZARENO, A. C.; AFFÉRRI, F. S.; PELUZIO, J. M.; CANCELLIER, L. L.; LEÃO, F. F.; NAOE, L. K. Avaliação de cultivares de mamona em três ambientes, no estado do Tocantins, safra 2007/2008. Bioscience Journal, Uberlândia, v. 27, n. 2, p. 297-304, 2011.

OLIVEIRA, E. M. Avaliação do teor de óleo e peso em sementes de mamona utilizando diversos acessos. Engenharia Ambiental, Espírito Santo do Pinhal, v. 8, n. 1, p. 205-211, 2011.

PEIXOTO, M. L.; MORAES, J. C.; SILVA, A. A.; ASSIS, F. A. Efeito do silício na preferência para oviposição de Bemisia tabaci biótipo b (genn.) (hemiptera: aleyrodidae) em plantas de feijão (Phaseolus vulgaris L.). Ciência e Agrotecnologia, Lavras, v. 35, n. 3, p. 478-481, 2011.

PIMENTEL, C.; SARR, B.; DIOUF, O.; ABBOUD, A. C. S.; MACAULEY, H. R. Tolerância Protoplasmática foliar à seca, em dois genótipos de caupi cultivadas em campo. Revista Universidade Rural. Série Ciências da Vida, Rio de Janeiro, v. 22, n. 1, p. 7-14, 2002.

PRADO, R. M.; NATALE, W. Efeitos da aplicação da escória de siderurgia ferrocromo no solo, no estado nutricional e na produção de matéria seca de mudas de maracujazeiro. Revista Brasileira de Fruticultura, Jaboticabal, v. 26, n. 1, p. 140-144, 2004.

SEVERINO, L. S.; FERREIRA, G. B.; MORAES, C. R. A.; GONDIM, T. M. S.; FREIRE, W. S. A.; CASTRO, D. A.; CARDOSO, G. D.; BELTRÃO, N. E. M. Crescimento e produtividade da mamoneira adubada com macronutrientes e micronutrientes. Pesquisa Agropecuária Brasileira, Brasília, DF, v. 41, n. 4, p. 563568, 2006.

SHANNON, M. C.; GRIEVE, C. M.; FRANCOIS, L. E. Whole-plant response to salinity. In: WILKINSON, R. E. Plant environment interactions. New York: Marcel Dekker Inc., 1994. p. 199-244.

SILVA, G. F.; OLIVEIRA, G. S.; NASCIMENTO, J. J. V. R.; PEREIRA, R. G.; PAIVA, M. R. F. C. Germinação e crescimento inicial de mamoneiras irrigadas com água salina em diferentes volumes de substrato. Revista Verde de Agroecologia e Desenvolvimento Sustentável, Mossoró, v. 6, n. 2, p. 135-142, 2011.

SILVA, S. M. S. Germinação, crescimento e desenvolvimento de genótipos de mamoneira irrigados com águas salinas. 2004. Dissertação (Mestrado em Engenharia Agrícola) - Universidade Federal de Campina Grande, Campina Grande. 
SZABOLCS, I. Soil and salinization. In: MOHAMMAD, P. (Ed.). Handbook of plant and crop stress. New York: Marcel Dekker Inc., 1994. p. 3-11.

TAKEMURA, T.; HANAGATA, N.; SUGIHARA, K.; BABA, S.; KARUBE, I.; DUBINSKI, Z. Physiological and biochemical responses to salt stress in the mangrove, Bruguiera gymnorrhiza. Aquatic Botany, Philadelphia, v. 68, n. 1, p. 15-28, 2000.

YAHYA, A. Salinity effects on growth and uptake and distribution on sodium and some essential mineral nutrients in sesame. Journal of Plant Nutrition, Philadelphia, v. 21, n. 2, p. 1439-1451, 1998. 